\section{Barnekardiologi for frakkelommen}

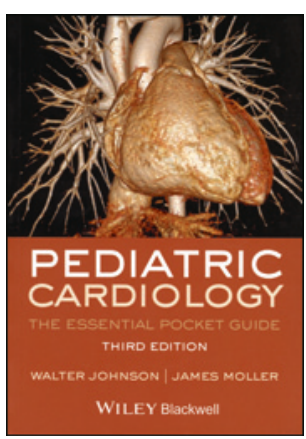

Walter H. Johnson, James H. Moller Pediatric cardiology

The essential pocket guide. 3. utg. $392 \mathrm{~s}$, tab, ill. Chichester: Wiley-Blackwell, 2014. Pris GBP 50

ISBN 978-1-118-50340-9

Denne boken er ment å være et praktisk hjelpemiddel i barnekardiologens kliniske hverdag på sentralsykehusnivå. I 12 kapitler presenteres alle de vanlige kardiologiske problemstillingene hos barn og ungdommer etter tradisjonell disposisjon, med vekt på diagnostikk. Klinisk vurdering og enkle supplerende undersøkelser, som EKG, vies forholdsvis stor plass. Ekkokardiografi er derimot omtalt forholdsvis kortfattet, og mer avanserte kartleggingsmetoder, som CT, MR og fysiske funksjonstester, er nesten ikke inkludert i det hele tatt. Behandling beskrives summarisk - dette er ikke en bok for kolleger på sykehus med tilgang til kirurgiske eller kateterbaserte metoder.

Det er mye tekst og få figurer - samtlige i svart-hvitt. En del av teksten står i ramme med grått raster - det dreier seg av og til om oppsummeringer, andre ganger er det vanskelig helt å forstå begrunnelsen for dette designgrepet.

Jeg lar meg ikke begeistre av denne utgivelsen. Ekkokardiografi er i dag tilgjengelig på alle norske barneavdelinger og er en uovertruffen metode for både anatomisk og hemodynamisk kartlegging. Da er detaljerte beskrivelser av subtile pulskarakteristika og auskultasjonsfunn av begrenset interesse. Plasmakonsentrasjonsmåling av peptidet proBNP er en enkel, tilgjengelig og nyttig undersøkelse for vurdering av hjertesvikt - men dette omtales ikke. Mange kolleger ville hatt nytte av enkle, oversiktlige beskrivelser av hvordan ulike medfødte hjertefeil skal håndteres - hva er for eksempel gjeldende indikasjon for invasiv utredning/behandling? Når skal pasienten henvises til et større senter? Men slike oversikter får man sjelden, og i den grad de presenteres, samsvarer de ikke alltid med norsk praksis.

Grundig hemodynamisk forståelse gir boken heller ikke, noe som for så vidt er rimelig, størrelsen tatt $\mathrm{i}$ betraktning. Men dermed blir også bruksområdet smalt - den er for stikkordpreget for nybegynnere i faget, og altså temmelig irrelevant for de erfarne. Konklusjon: Bruk pengene på noe annet!

Vegard Bruun Wyller

Tidsskriftet

\section{Intet er nytt i sosiale nettverk}

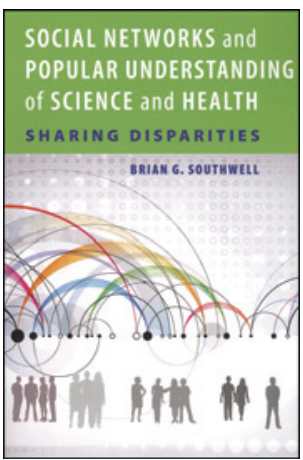

Brian G. Southwell

Social networks and popular understanding of science and health

Sharing disparities. 137 s, tab, ill. Baltimore, MD: The Johns Hopkins University Press,

2013. Pris USD 25

ISBN 978-1-4214-1324-2

Involvering er viktigere enn publisering. Informasjonen kommer ikke frem hvis den ikke engasjerer i de sosiale nettverkene. Dette er utgangspunktet for denne korte boken. Den er ment å gi et innblikk i teorier og forståelsesmodeller av forskning og helse innenfor sosiale nettverk. Ett av målene er å dokumentere forskjeller i tendens til å dele informasjon om helse og forskning.

I første del dokumenteres evidensen for informasjonsgapet som eksisterer, og hvordan det samme gapet ivaretas også i moderne sosiale nettverk. Forfatteren gjør godt rede for hvordan informasjonsgapet består, gjennom at informasjonsflyten i moderne sosiale nettverk bare repliserer gamle sosiale nettverk.

I den andre delen går forfatteren gjennom hvordan individ-, samfunns- og kontekstfaktorer påvirker hvordan informasjon deles. Delen er interessant, og han bruker en lang rekke eksempler på hvordan helseinformasjon både ved katastrofer, men også som en del av folkehelsekampanjer, har spredd seg. Dessverre er eksemplene svært mange og oftest bare helt overfladisk beskrevet. Det gjør at det er vanskelig å se hva forfatteren vil fortelle med eksemplene. De er dessuten i stor grad amerikanske, men selv ikke når norske antirøykekampanjer omtales, får jeg noe ut av eksemplene uten å gå via referansene og finne kampanjene selv.

I siste del, der forfatteren oppsummerer og ønsker å vise retning for hvordan informasjonsdeling i sosiale nettverk bør håndteres, synes jeg boken er uproporsjonalt kort. Mest interessant er det når forfatteren diskuterer om hvorfor ulik delingskultur er problematisk.

Som forlaget selv skriver, strekker temaene seg langt forbi sosiale medier. Dessverre strekker boken seg ikke like langt inn i dem. Omslagsteksten kunne forlede leseren til å tro at boken skulle fortelle mer om moderne sosiale nettverk, men dessverre blir dette bare helt overfladisk berørt. Dermed blir boken også mindre interessant for dem som er opptatt av helseinformasjon i nye sosiale medier.

Målgruppen er nok i størst grad samfunnsfagvitenskapelige studenter og personer som er engasjert i folkehelsekampanjer, og i noen grad også samfunnsmedisinere. For alle som tenker at enten nye eller gamle sosiale nettverk bidrar til bedre tilgjengelighet av helseinformasjon, er dette en nyttig påminnelse om at det sannsynligvis ikke er sånn.

Ole Kristian Losvik

Fastlegevikar, Greverud legesenter 